\title{
W poszukiwaniu prawdy w naukach o kulturze
}

\begin{abstract}
The question of the truth is of great importance for social sciences and humanities today. No matter how much they focus on the dynamics of changes in the human world, the criterion of their credibility is whether they can use reporting knowledge to predict the future. To pay off their debt, these sciences are looking for a tool that allows them, if not discovering the truth, then at least (gradually) approaching it. This task has two difficulties. First of all, what is the truth understood as the final product of science. Secondly, by what method its representatives can seek the truth about what cultural reality is? What form does it take in our time? This article is devoted to these considerations.
\end{abstract}

Keywords: the truth, performative turn, patterns of culture, heteronomy

\section{Wstęp}

ytanie o prawdę może wprawiać w zakłopotanie. Nie dzieje się tak bez przyczyny. Prawda jest pojęciem wieloznacznym. W logice dwuwartościowej sytuuje się ona obok fałszu rozumianego jako druga wartość logiczna. Jedna z tych wartości - prawda lub fałsz - przypisywana jest dowolnej wypowiedzi przybierającej kształt zdania oznajmującego. Z tym nikt nie dyskutuje. Aby być zrozumiałym, trzeba się logicznie wypowiadać. W ujęciu ontologicznym (względnie ontologiczno-teologicznym) prawda dotyczy bytu, któremu przysługuje cecha istnienia w stopniu najwyższym. Filozofowie pytają o to, co jest, badacze biblijni przypominają historię Mojżesza, któremu Bóg przedstawił się jako Ten, który Jest (Księga 
Wyjścia 3,14). Przytoczone sformułowania dotyczą tyleż stanu faktycznego, co treści esencjalnych składających się na ów stan. Arystoteles konstruuje w tym celu definicję istotnościową. Opis wybranego fragmentu rzeczywistości polega na przypisaniu mu cechy gatunkowej oraz gatunkowego wyróżnika (per genus proximum et differentiam specificam). Na przykład, człowiek zostaje zdefiniowany przez Arystotelesa jako zóon lógikon (łac. animal rationale). Jego wyróżnikiem, poza zwierzęcą cechą rodzajową, jest jego rozumność. Ten sposób nabywania wiedzy o otaczającym nas świecie w ostatecznym rozrachunku prowadzi do pytania o jego najwyższe prawa. W zależności od preferowanego światopoglądu do tychże praw mogą być zaliczone prawa natury bądź zasady pochodzące spoza świata przyrody.

Wzmiankowana dowolność odsłania istotę problemu‥ Prawda w zastosowaniu ontologicznym napotyka przeszkodę w postaci rozbieżnych przekonań (doxa) dotyczących zastanego porządku rzeczy. Aby przekonania te potwierdzić względnie porównać z tym, co myślą inni, konieczne jest posłużenie się epistemologicznym kryterium prawdy. Dopiero ono pozwala na uzasadnienie roszczenia do ważności sądów na temat tego, jak urządzony jest świat. Według Arystotelesa prawda w tym ujęciu odnosi się do adekwatności związków łączących jedno z drugim (adaequatio rei et intellectus). Otwarta pozostaje kwestia, czy wiedza o tych związkach (episteme) - w każdym wypadku - zachowuje nadrzędny status wobec indywidualnych przekonań. Poznawcza dostępność świata w postaci wiedzy powszechnej i koniecznej budzi wszak wątpliwości. Z całą pewnością natomiast odmowa skonfrontowania tego, co głoszą uczestnicy debaty o tym, co jest (wymiar ontologiczny prawdy), z argumentami dowodzącymi (epistemologicznej) prawdziwości ich sądów, skazuje to przedsięwzięcie na niepowodzenie.

Tymczasem z ustaleń dotyczących porządkujących funkcji epistemologii w rozważaniach o tym, co jest, nie należy wyciągać nazbyt pochopnych wniosków. Jest to raczej zależność zwrotna. Aby to wyjaśnić, warto ponownie przywołać Arystotelesa. Jego epistemologiczny optymizm (dotyczący dostępu do prawdy jako zgodności rzeczy i umysłu) poprzedza założenie ontologiczne w postaci zasady niesprzeczności. Przywoływana jest ona zwykle jako zasada logiczna. Warto jednak pamiętać, że Arystoteles nadaje jej szersze znaczenie. Odnosi ją mianowicie do natury świata i ludzkiego umysłu. Właśnie dlatego możliwa jest poznawcza zgodność (adekwatność) pomiędzy nimi, że są one wolne od paradoksów, na których skupiali się jej poprzednicy. Inaczej niż tragediopisarze, których motywem przewodnim był konflikt tragiczny czy sofiści zachęcający do tworzenia „własnej miary wszystkich rzeczy”, perypatetycy traktują świat jako przestrzeń

${ }^{1}$ Kiedy piszę o „wzmiankowanej dowolności” mam na myśli - przywołaną w ostatnim zdaniu wcześniejszego akapitu - dwuznaczność zawierającą się w pojęciu „najwyższych praw”. Dwuznaczność ta odnosi się bądź to do „praw natury”, bądź do „zasad pochodzących spoza przyrody". 
poznawczych penetracji człowieka. Oto przykład ontycznych przesłanek ukrytych za epistemologicznym projektem.

Czy Arystoteles i jego następcy mieli rację? Od czasów Nietzschego jest to jedno z kluczowych pytań humanistyki. Prawda jako kategoria poznawcza (z konieczności) uwikłana jest w wyobrażenia badacza o tym, co badane. To owe wyobrażenia pozwalają mu na dobór środków odpowiadających jego domniemanym potrzebom badawczym. I vice versa. Nazbyt duże przywiązanie do prawdy jako reprezentacji tego, co jest, pozbawia jej wyznawcę możliwości sprawdzenia jej „,adekwatności” z tym, czego doświadcza on na co dzień. Fakty niewygodne albo nie są przez niego dostrzegane, albo „przestają mieć znaczenie”. Z opisu obu krańcowości wynika, że łatwo tu o dogmatyzm. Pułapka ta czyha zarówno na tych, którzy przeakcentowali rolę teorii poznania w procesie odkrywania prawdy o świecie, jak i na tych, którzy (a priori) zwolnili się z obowiązku respektowania epistemologicznego wymogu potwierdzenia własnych przekonań. Prawidłowość ta odnosi się do niemal wszystkich przejawów intelektualnej aktywności człowieka. Naukowiec z zaciekłością broniący starzejącej się teorii, niezdolny do wyjaśnienia - za jej pomocą - anomalii dotykających jej paradygmatycznych podstaw, niewiele różni się od religijnego fundamentalisty. Pociechą jest to, że poglądy jednego i drugiego weryfikuje praktyka. Niestety, na jej pomoc nie mogą liczyć badacze kultury. Dlatego w ich wypadku tak ważne jest zachowanie dyscypliny w formułowaniu hipotez wstępnych oraz ocenie ich prawdziwości.

W badaniach kulturowych - bardziej niż ma to miejsce w przypadku badań przyrodniczych czy (wąsko pojętych) badań społecznych - odniesienie do praktyki, traktowanej jako poszukiwane kryterium prawdy, znajduje znikome zastosowanie. Wobec wielości i różnorodności treści składających się na obraz kultury, stanowisko to może dziwić. Tymczasem właśnie one sprawiają, że kryterium praktyki zawodzi. Kryterium to bowiem poddaje się zniekształceniom polegającym na selekcji treści wykorzystanych w procesie systematyzacji wiedzy o danej kulturze. Nie szukając daleko, Jan Sowa głosi, że kultura polska pozbawiona jest „,...] poważnych osiągnięć, które wywarłyby wpływ na kulturę europejską, nie mówiąc już o światowej”2. Andrzej Leder natomiast obwinia Polaków o ich „transpasywny udział” w zbrodniach wojennych Niemców i Rosjan. Udział ten rozciąga nie tylko na zbrodnie przeciwko Żydom, lecz także przeciw polskim elitom³. Można - bez trudu - znaleźć przykłady kulturowych zapóźnień czy aktów przemocy, na które powołują się obaj autorzy. Cóż jednak począć z problemem reprezentatywności owych danych? Nieoczywistość konkluzji uzasadnionej za ich pomocą ilustruje, jak praktyka - „skompletowana” z danych skądinąd prawdziwych - może przybierać postać wysoce wątpliwego sprawozdania. Wątpliwości towarzyszące

2 J. Sowa, Fantomowe ciało króla. Peryferyjne zmagania z nowoczesną formq, Universitas, Kraków 2011, s. 18.

${ }^{3}$ A. Leder, Prześniona rewolucja. Ćwiczenie z logiki historycznej, Wydawnictwo Krytyki Politycznej, Warszawa 2014, s. 29. 
poszukiwaniom prawdy w kulturze nie tylko nie znikają, lecz zostają wzmocnione niejasnościami dotyczącymi sposobu prowadzenia owych poszukiwań.

Z dokonanych ustaleń wynika, że ograniczenia kompetencyjne, przekonania normatywne badacza oraz jego preferencje metodologiczne są nieusuwalnym składnikiem badań kulturowych ${ }^{4}$. Badacz musi posłużyć się - przyjętym w postaci założenia wstępnego - modelem kultury, aby przeprowadzić badanie. Tego modelu dotyczy pytanie o prawdę odkrywaną przez nauki o kulturze. Bez niego, badania kulturowe skazane będą na przyczynkarstwo lub przypadkowość. On sam natomiast może prowadzić do błędów wynikających z tendencyjnego charakteru postępowania badawczego. Czy zatem wszystko jest stracone? W żadnym razie. Po stronie atutów chroniących badacza przed nim samym umieścić należy (1) jego metodologiczne rozeznanie w kwestii jego uwikłań w proces badawczy oraz (2) jego świadomość celów możliwych do osiągnięcia w przypadku kultury rozumianej jako rzeczywistość złożona, dynamiczna i (aksjologicznie) niejednorodna. W swoim artykule zamierzam bronić tezy, iż wymienione dyrektywy badawcze pozwalają naukom o kulturze przybliżać się do prawdy o tym, co stanowi ich przedmiot. Decyduje o tym ich zdolność poddawania cyklicznej ocenie adekwatności modeli, którymi one posługują się. Mogą to czynić na podstawie danych szczegółowych pod warunkiem zachowania wstrzemięźliwości w ich selekcjonowaniu, czy - tym bardziej - zamiany w „spójny obraz praktyki kulturowej”. Zwłaszcza wtedy, gdy owe dane przybierają postać anomalii, chronią badacza przed pułapką dogmatyzmu. Przypominają mu mianowicie, z jak poważnymi wyzwaniami się mierzy.

\section{Kultura jako przedmiot badania. Ujęcie historyczne}

Pytanie o prawdę w kulturze napotyka przeszkody omówione w poprzednim paragrafie. Najważniejsze spośród nich dotyczą zależności łączącej wiedzę o zawartości danej kultury z ustaleniami (wstępnymi) na temat tego, czym - w ujęciu modelowym - jest kultura. Sposób definiowania tej zależności ma ogromne znaczenie. Zależy od niego bowiem to, co stanowić ma (właściwy) przedmiot badania. Reszta jest konsekwencją przyjętych założeń. Model kultury wraz z preferencjami metodologicznymi badacza kształtuje (bądź odzwierciedla) jego przekonania o poznawczej dostępności świata kultury oraz o wpływie kulturowych komponentów na jego mieszkańców. Komponenty te mogą zafałszowywać świadomość zwykłych ludzi, tak jak świadomość badacza mogą zniekształcać jego błędne wyobrażenia o tym, co bada. Konsekwencje owych błędów są poważne. Skutkują dogmatycznym

${ }^{4}$ Kiedy piszę o „dokonanych ustaleniach”, mam na myśli - przywołaną we wcześniejszym akapicie - wątpliwość dotyczącą praktyki jako poszukiwanego w badaniach kulturowych kryterium prawdy. Wątpliwość tę zilustrowałem przykładami „,zniekształceń polegających na selekcji treści wykorzystanych w procesie systematyzacji wiedzy o danej kulturze”. 
stosunkiem do kultury przejawiającym się arbitralnym przypisaniem jej wybranych cech (rzekomo świadczących o jej autentyczności bądź o jej braku autentyczności) lub przesłonięciem problematyki kulturowej sprawami należącymi do porządku psychologicznego i społecznego. Stosunkowo łatwo rozpoznać wymienione błędy, natomiast zdecydowanie trudniej wystrzec się ich w prowadzonych badaniach. Dlaczego? Najwyraźniej trudno nam rozstać się z nawykami badawczymi kierującymi nas w jedną lub drugą stronę. Skąd jednak wzięły się te nawyki? Odpowiedzi na to pytanie dostarcza historia nauk o kulturze.

W złotym wieku Aten poeci i tragediopisarze skupiają się na motywie uwikłania człowieka w konflikt wartości. Edyp, Antygona, Elektra z pozoru tylko panują nad swoim losem. Wybory, jakich dokonują, w żaden sposób nie chronią ich przed zgubnym wpływem fatum. Doświadczenie niepewności jutra urasta w tamtych opowieściach do miana rozpoznania ontologicznego. Uczestnicy antycznego spektaklu identyfikują się z postaciami dramatu, rzec by można, bez reszty. Zapewne dlatego Arystoteles w Poetyce definiuje katharsis jako zdolność doświadczania prawdziwych uczyć pod wpływem artystycznego (tzn. inscenizowanego) przekazu 5 . Tymczasem tragediopisarzom przeciwstawiają się sofiści. Protagoras wierzy, że dzięki rozumowi, ,jako mierze wszystkich rzeczy”, człowiek potrafi kontrolować to, co go spotyka. Niestety, wyznawcy tego poglądu albo kwestionują istnienie obiektywnych reguł słusznego postępowania, albo rezygnują z nadziei na ich poznawczą selekcję. Wybór, przed którym staje podmiot, dotyczy tego, czy sam będzie ustalał zasady rządzące jego życiem, czy narzucą mu je inni. Granica oddzielająca doxa od episteme (przekonania od wiedzy) nie zostaje przekroczona, ani w jednym, ani w drugim przypadku. Sofiści uważają, że świat wartości jest heterogeniczny. Zdawanie sprawy ze świata i rządzących nim praw, aby było zrozumiałe - choćby dla jego autora - musi być natomiast spójne. Stąd niewspółmierność zachodząca pomiędzy jednorodnością myślenia a różnorodnością tego, co opisywane (i zagospodarowywane).

Wiarę sofistów w porządkującą moc rozumu, jako niepewnej przeciwwagi dla wszechobecnego fatum, podaje w wątpliwość Sokrates. Choć nie kwestionuje on tezy o heterogenicznej naturze rzeczywistości kulturowej, to pozbawia podmiot inicjatywy w zakresie jej nieskrępowanego porządkowania. Wartościom kulturowym Sokrates przeciwstawia areté (cnotę). Aksjologiczne ograniczniki znajdujące się po stronie podmiotu zmuszają go do powściągliwości w sądzeniu. Podmiot ów mianowicie godzi się z myślą, że jedyną wiedzą prawomocną (episteme), jest wiedza odnosząca się do jego niewiedzy. Stanowisko zajęte przez Sokratesa jest logiczną konsekwencją założeń przyjętych przez sofistów oraz przez niego samego. Zarazem jest końcem humanistyki uprawianej według heteronomicznego

${ }^{5}$ Arystoteles, Poetyka, tłum. H. Podbielski, Zakład Narodowy im. Ossolińskich, Wrocław 1983, ss. 26-29. 
wzorca ${ }^{6}$. Wyznawca poglądów Sokratesa postępowałby wbrew sobie, modelując rzeczywistość za pomocą własnych wyobrażeń stanu pożądanego. Niczym innym zaś nie dysponuje. Zapewne dlatego następcy Sokratesa dokonują wyboru metod badawczych bliskich pojęciu racjonalności homogenicznej (albo zasadzie niesprzeczności). Platon umieszcza świat idei ponad - pełnym paradoksów - światem materialnym; Arystoteles czyni z zasady phronesis (mądrość praktyczna) przepis na pomyślność własnej wspólnoty losu, docelowo zaś - pomyślność tego, kto postanowił zadbać o własne otoczenie polityczne.

Wzorce racjonalności homogenicznej - ujmując rzecz skrótowo - pozostają w mocy do naszych czasów. Przełomowym momentem w historii nauki są narodziny nowoczesnego przyrodoznawstwa. „Matematyzacja przyrody”, dokonana przez Galileusza na przełomie XVI i XVII wieku, utwierdza niedowiarków w przekonaniu o poznawczej ,,adekwatności rzeczy i umysłu”. Tymczasem sukces technologiczny odniesiony przez człowieka Zachodu z trudem przekłada się na jego bezpieczeństwo, samospełnienie czy poczucie szczęścia. Pomimo wielokrotnie zapowiadanej poprawy jego losu, pozostaje on więźniem schematów myślowych, tyleż otwierających go na określone sfery doświadczenia, co przesłaniających mu części wyłączone z powodu ich treściowej niewspółmierności. Dyskusje wokół natury człowieka, modelu ustrojowego państwa demokratycznego czy źródeł społecznej anomii są tego najlepszym przykładem.

Przełom przynosi wiek XIX. Dynamiczny rozwój świata zachodniego - rozwój kulturalny, polityczny, gospodarczy - sprawia, że na znaczeniu zyskuje krytyka logocentryzmu. Do rangi symbolu urastają - w tym kontekście - dokonania Friedricha Nietzschego. Głosi on, że warunkiem pełnego uczestnictwa w kulturze jest skonfrontowanie się z prawdą o jej heteronomicznej naturze. Zaproponowane przez autora Poza dobrem i złem rozróżnienie między apollińskim i dionizyjskim modelem dobrego życia - funkcjonującymi równolegle w antyku greckim - służy ujawnieniu uchybień i braków zawierających się w kulturze Zachodu końca XIX wieku . Postępująca systematyzacja zasad myślenia i działania doprowadziła przedstawicieli tej kultury do wydajności produkcyjnej i organizacyjnej niespotykanej w dziejach ludzkości. Wraz z tym jednak pozbawiła ich dostępu do wiedzy radosnej (la gaya scienza), decydującej o ich umiejętności wyboru tego, co ważne dla każdego z nich z osobna.

Nietzsche ma wielu kontynuatorów. Potwierdzają oni na różne sposoby zasadność jego diagnozy dotyczącej destrukcyjnych skutków rezygnacji z rozbieżnych kryteriów oceny ludzkiego postępowania. Przedmiotem rozważań staje się świat życia człowieka (Lebenswelt) kolonizowany przez naukę, technikę, a przede

${ }^{6}$ P. Rotengruber, Man in a World of Values. What is Applied Cultural Studies?, „Journal of Applied Cultural Studies” vol. I, Poznań 2015, ss. 7-15.

${ }^{7}$ F. Nietzsche, Poza dobrem i złem, tłum. S. Wyrzykowski, Warszawa 1983, s. 21. Por. idem, Narodziny tragedii albo Grecy i pesymizm, tłum. B. Baran, Kraków 1994, s. 91. 
wszystkim przez system administracyjno-gospodarczy. Martin Heidegger opisuje proces zamykania się prześwitu ludzkiej przytomności (Lichtung), przedstawiciele szkoły frankfurckiej głoszą, iż człowiek padł ofiarą świadomości fałszywej. Autorzy ci otwierają długą listę radykalnych krytyków kultury zachodniej. Błędem byłoby tymczasem zawęzić opowieść o zmianach zachodzących w humanistyce współczesnej do ich wystąpień. Mniej radykalni badacze skupiają się na środkach, za pomocą których człowiek orientuje się we własnym położeniu oraz porozumiewa się z innymi ludźmi.

W pierwszym wypadku inicjatywę przejmują zwolennicy podejścia do prawdy jako kategorii trwale powiązanej z praktyką interpretowania świata na podstawie dostępnych danych. Ilustruje tę zależność pojęcie koła hermeneutycznego wprowadzone (najprawdopodobniej) przez Friedricha Schleiermachera, a spopularyzowane przez Hansa-Georga Gadamera. Jest ono metaforą czynności polegającej na rekonstrukcji wzorów (określonej) kultury na podstawie szczątkowych informacji o nich. Fragmenty nie mówią wiele o obrazie całości. Badacz musi więc stworzyć hipotezę, za pomocą której nada ogólne znaczenie informacjom szczegółowym. Informacje te następnie wykorzystuje on do potwierdzenia swojej hipotezy. Jeśli jest tu miejsce na pytanie o prawdę, to odnosi się ono do ustaleń dokonywanych w dialogu z autorami konkurencyjnych hipotez.

W drugim wypadku zamiar dogadania się z innymi ludźmi odniesiony zostaje do Nietzscheańskiego pytania o prawdę i kłamstwo słów. Tradycyjne koncepcje języka jako pomostu łączącego rzeczy i umysł (rei et intellectus) ustępują miejsca rozważaniom dotyczącym nieprzekładalności kodów językowych (post-analitic philosophy), intencji nadawcy komunikatu językowego (Ludwig Wittgenstein, John Austin, John Searle) czy jego pozawerbalnych aspektów możliwych do uwzględnienia dopiero po zastosowaniu gęstego opisu zdarzenia komunikacyjnego (Gilbert Ryle, Clifford Geertz). W wymienionych propozycjach na uwagę zasługuje wielość kryteriów decydujących, z jednej strony, o czytelności komunikatu, a z drugiej - o sposobie, w jakim został on wyartykułowany. Owszem, jego nadawca musi uwzględnić możliwości percepcyjne tych, do których się zwraca. Nie oznacza to jednak pozbawienia go inicjatywy w zakresie tego, co chce powiedzieć oraz jak zamierza to uczynić. Przeciwnie, nowa humanistyka otwiera przed nim całą paletę takich możliwości. Pomiędzy jednym i drugim odkrywa on prawdę o porządku świata, do którego przynależy.

\section{Kultura jako obszar poszukiwania prawdy}

Z uwag podsumowujących poprzedni paragraf wynika, że cechą toczącego się dziś sporu o prawdę w kulturze jest jego wielowątkowość. Jego uczestnicy zwracają uwagę na takie kwestie, jak adekwatność (dowolnej) teorii do praktyki kulturowej, możliwość efektywnego komunikowania treści uchodzących za prawdziwe 
czy (poznawczy) dostęp człowieka do wiedzy o sobie samym. Rzecz jasna, lista problemów nie kończy się na tych pytaniach. One jednak odgrywają kluczową rolę w rozważaniach na temat prawdy pojętej jako doświadczenie wspólnotowe. Przez analogię do ustaleń Gorgiasza z Leontioi i Protagorasa z Abdery, są tą wyzwania, którym muszą stawić czoła nauki o kulturze. Muszą to uczynić pod rygorem utraty własnej wiarygodności. Stwierdzenie to określa dalszy tok postępowania. Od kulturoznawców, etnologów czy performatyków zależy, jakie wnioski wyciągną z historii dyscyplin, które reprezentują. Jest tymczasem o co upominać się. Przedstawiciele nauk o kulturze lokują się w szpicy autorów opowiadających się za zmianą podejścia do (szeroko pojętych) badań humanistycznych i społecznych. Niestety, ich deklaracje nie (zawsze) przekładają się na działania uprawdopodabniające ich powrót do antycznego ideału „tworzenia miary wszystkich rzeczy” składających się na kulturę (rozumianą jako rzeczywistość aksjologicznie zróżnicowana). Skąd ten wniosek?

Mankamentem głównym nauk o kulturze jest ich rozdarcie pomiędzy ciążeniami ontologicznymi (starego typu) a nazbyt szerokim (epistemologicznym) otwarciem na zmiany dokonujące się w kulturze współczesnej. Przykładów ilustrujących oba przypadki jest bez liku. Oto niektóre z nich. Przedstawiciele brytyjskich studiów kulturowych rozpoczynają swoje badania od deklaracji dotyczącej ich przywiązania do materializmu historycznego oraz strukturalizmu․ Owszem, owo rozdwojenie dobrze wróży badaniom zorientowanym na kulturową różnorodność. Wraz z tym jednak zawęża problematykę badawczą do marksistowskich dystynkcji. Pytanie o stan kultury poprzedzone zostaje mianowicie ustaleniami dotyczącymi tego, „,co oczywiste” (tzn. tego, czego badać nie trzeba). Mniej złożone postaci błędu, o którym mowa, jak refren powracają w badaniach polskich badaczy kultury. Ryszard Legutko pisze o „polskiej duszy” - po II wojnie światowej - zainfekowanej chorobą komunizmu, Józef Tischner natomiast o piętnie homo sovieticusa wyciśniętym na społeczeństwie polskim przez PRL ${ }^{9}$. Nie czas i miejsce na to, by wyjaśniać podobne nieporozumienia. Dość powiedzieć, że w badaniach prowadzonych według tego scenariusza zaciera się granica oddzielająca przesłanki badawcze od problemów wymagających zbadania.

Niewiele lepiej ma się sprawa z radykalnymi zwolennikami rozmontowywania kulturowych (aksjologicznych) regularności. Badacze ci bowiem popadają w drugą skrajność. Pośród kulturowej różnorodności nie dostrzegają elementów integrujących jej uczestników, względnie marginalizują znaczenie tych elementów. Na przykład Jon McKenzie głosi, że kultura Zachodu podlega zmianom wywołanym

${ }^{8}$ Por. M. Kosińska, Problemy analizy kulturowej, Wydawnictwo Naukowe WNS UAM, Poznań 2017.

9 J. Tischner, Etyka solidarności oraz Homo sovieticus, Znak, Kraków 2005. Por. A. Zinowiew, Homo sovieticus, tłum. S. Deja, Horyzont, Warszawa 1987; R. Legutko, Esej o duszy polskiej, Zysk i S-ka, Poznań 2012, s. 3. 
przez „zwrot performatywny”. Polegają one na zużywaniu się „modelu dyscypliny”, którego zbiorowym użytkownikiem były do niedawna „społeczeństwa kontroli”. W wyniku tego procesu model dyscypliny ustępuje miejsca nowej formacji kulturowej. McKenzie pisze o wyłanianiu się „warstwy performatywnej” ${ }^{10}$. Regularności charakterystyczne dla niedawnych form życia zbiorowego napotkają - jego zdaniem - przeszkodę w postaci „sił odśrodkowych”, widomym przejawem których są powojenne ruchy społeczne i artystyczne. W tym zakresie wnioski, do których doszedł McKenzie, są bezdyskusyjne. Zarówno krytycy demokracji zachodniej, jak i jej apologeci dostarczają argumentów potwierdzających tę tezę. Czymś innym natomiast jest podążające $\mathrm{w}$ ślad za tym domniemanie o możliwości zastąpienia modelu dyscypliny sumą działań oddolnych. Przeczą temu performanse polityczne i biznesowe. Najwyraźniej instytucje reprezentujące obie dziedziny kultury rozpoznały obecność sił odśrodkowych i nauczyły się wykorzystywać je z pożytkiem dla siebie. Jeśli uwzględnić przy tym sprawność integracyjną i perswazyjną owych instytucji, pod znakiem zapytania staje domniemanie odnośnie do performatywnych obszarów wolności ich społecznego otoczenia ${ }^{11}$.

To prawda, że kultura ewoluuje. Dynamika zachodzących w niej zmian w różnym stopniu odnosi się jednak do jej poszczególnych części. Spór polityczny bądź konsultacje w sprawie nowej regulacji prawnej nie są tym samym, co ingerencje w przekonania, za pomocą których wspólnota kształtuje własną tożsamość kulturową. To przecież owe przekonania skłaniają wspólnotę do (restrykcyjnej) ochrony takich wartości, jak „,wolność”, „racjonalność” czy „sprawiedliwość”. Proces ten ma swoją historię prowadzącą do wyłonienia się wzorów kultury - wartości i symboli, za pomocą których ich użytkownicy rozpoznają otaczającą ich rzeczywistość. Aby potwierdzić poprawność własnych ustaleń, ocenić przydatność owych wzorów, muszą oni posłużyć się nimi. Krytyczny dystans do nich to przecież nic innego niż rezultat posługiwania się nimi. To nie wszystko. Wzory kultury nowoczesnejzwłaszcza te z nich, którym towarzyszy uzasadnienie funkcjonalne - tworzą spójny system przekonaniowy. Dlatego ich odrzucenie wymaga całościowego podejścia. Jeśli przedsięwzięcie to ma się udać, musi inicjować zmiany paradygmatyczne w sensie, jaki temu pojęciu nadał Thomas S. Kuhn" ${ }^{12}$. To zaś łatwiej powiedzieć, niż zrobić.

10 J. McKenzie, Perform Or Else: From Discipline to Performance, London, Routledge, 2001, ss. 175-176. Por. R. Schechner, Performance Studies. An Introduction, Routledge, London and New York 2002, ss. 95-96.

${ }^{11}$ Podkreślenia wymaga, iż chodzi tu o coś więcej niż opór przed przemocą możnych tego świata. Posłuszeństwo wobec władzy politycznej i gospodarczej uzasadnia szereg argumentów funkcjonalnych. Lubimy nasze dostatnie życie, czujemy się obywatelami, cenimy sobie bezpieczeństwo, jakie daje nam przynależność do zachodniej organizacji państwowej. Nawet wtedy, gdy sprzeciwiamy się jej, mamy wszelkie podstawy, by udział w sporach z politycznych (i wszelkich innych) traktować jako dobrodziejstwo liberalnej demokracji.

12 T.S. Kuhn, Struktura rewolucji naukowych, tłum. H. Ostromęcka, PWN, Warszawa 1968. 


\section{Tytułem podsumowania}

Z dokonanego zestawienia wynika, że poszukiwanie prawdy o kulturze (oraz o jej zawartości) należy prowadzić z uwzględnieniem wymienionych skrajności. Preferowany przez badacza model kultury tyleż pomaga mu w określeniu przedmiotu badania, co (imaginatywnie) przesłania mu ów przedmiot. To zamyka sprawę. Nie ma przecież większego sensu badanie czegoś, co zostało przyjęte w postaci założenia wstępnego. Dlatego trzeba odwrócić kolejność. Oczekiwanym początkiem postępowania badawczego jest pytanie o stan kultury. Aby odpowiedzieć na nie, potrzebne są narzędzia umożliwiające gromadzenie danych na jej temat. Dopiero w tym postępowaniu pomocna staje się refleksja ontologiczna (odsyłająca na powrót do modelu kultury). Jest pomocna o tyle, o ile chroni badacza przed arbitralnym zawężeniem pola badania do wyselekcjonowanych przez niego cech kultury. Tego mu czynić nie wolno. Aby badanie zostało rzetelnie przeprowadzone, konieczna jest teoria otwierająca badacza na wielość i różnorodność informacji pochodzących ze świata kultury. To przesądza o przewadze modelu heteronomicznego nad logocentrycznym podejściem do postulowanych badań. Jeśli zebrane dane poddadzą się ujednoliceniu i hierarchizacji, podsumowaniem zbyt szeroko prowadzonego postępowania będzie jednorodny opis całości. Cóż jednak, gdy owe dane odnosić się będą do różnych wzorów uczestnictwa w życiu zbiorowym? O tym przekona się tylko ten badacz, który zawczasu uwzględnił taką ewentualność.

\section{Literatura}

Arystoteles, Poetyka, tłum. H. Podbielski, Zakład Narodowy im. Ossolińskich, Wrocław 1983.

Kosińska M., Problemy analizy kulturowej, Wydawnictwo Naukowe WNS UAM, Poznań 2017.

Kuhn T.S., Struktura rewolucji naukowych, tłum. H. Ostromęcka, PWN, Warszawa 1968.

Leder A., Prześniona rewolucja. Ćwiczenie z logiki historycznej, Wydawnictwo Krytyki Politycznej, Warszawa 2014.

Legutko R., Esej o duszy polskiej, Zysk i S-ka, Poznań 2012.

McKenzie J., Perform Or Else: From Discipline to Performance, London, Routledge, 2001.

Nietzsche F., Narodziny tragedii albo Grecy i pesymizm, tłum. B. Baran, Kraków 1994.

Nietzsche F., Poza dobrem i złem, tłum. S. Wyrzykowski, Warszawa 1983.

Rotengruber P., Man in a World of Values. What is Applied Cultural Studies?, „Journal of Applied Cultural Studies” vol. I, Poznań 2015.

Schechner R., Performance Studies. An Introduction, Routledge, London and New York 2002. 
Sowa J., Fantomowe ciało króla. Peryferyjne zmagania z nowoczesna forma, Universitas, Krakw 2011.

Tischner J., Etyka solidarności oraz Homo sovieticus, Znak, Kraków 2005.

Zinowiew A., Homo sovieticus, tłum. S. Deja, Horyzont, Warszawa 1987. 
